\title{
SIMULATION OF DYNAMIC MODES IN THE ASYNCHRONOUS MOTOR
}

\section{Viktor Lyshuk $^{1}$; Yosyp Selepyna ${ }^{1}$; Sergiy Kostiuchko'; Sergiy Litkovets ${ }^{2}$}

\author{
${ }^{1}$ Lutsk National Technical University, Lutsk, Ukraine \\ ${ }^{2}$ National University of Water and Environmental Engineering, Rivne, Ukraine
}

\begin{abstract}
Summary. The mathematical model of asynchronous three-phase motor, which takes into account the saturation of the magnetic system, is constructed in this paper. The system of differential equations of the electromagnetic state is formed in the normal Cauchy form. This form of equations presented in the matrix form is very convenient for numerical integration, since it is implemented by explicit methods that are simpler in computer realization than implicit ones. This approach makes it possible to describe the complex physical processes in the motors, namely the effect of saturation of the magnetic circuit and mechanical rotational motion. The use of the proposed model of the asynchronous motor, created by its real passport data, provides an opportunity for adequate real-time modeling. FORTRAN programming language and graphic editor GRAPHER are used to calculate dynamic regimes. The explicit Euler method is used for numerical integration of differential equations. The proposed model can be used to analyze the modes of operation of the motors as an autonomous element and an element of the electromechanical system. It is shown that this model corresponds to the classical theory of electric machines.
\end{abstract}

Key words: differential equations, mathematical model, asynchronous motor, numerical methods.

Statement of the problem. The methods of mathematical modeling rely on powerful computer facilities and related software enabling to implement computational experiment. Very often in practice the experiment on the real object is replaced by its mathematical model as it is either difficult or impossible to carry it out because of high cost. Nowadays mathematical models are powerful tools of investigation of various electronic devices, and numerical methods of differential equations solving are being increasingly used for analysis of dynamic processes in electrical engineering. These processes are usually described by nonlinear differential equations $[5,7]$.

It is well known that the solution of the differential equation is a certain function which depending on sampling spacing and finite integration time can reach dozens-hundreds of thousand points requiring calculations. It is impossible to solve such equation manually because of huge amount of work. In this case the equations integration by numerical methods should be used [6]. Equations with ordinary derivatives are solved by explicit or implicit Euler or RungeKutta methods. This is implemented by means of appropriate mathematical methods and programming [6].

By solving the equation at certain initial conditions we determine what happens with devices during their operation life. Therefore the solution of dynamics differential equations is the basis for analysis of operational characteristics of electrical devices.

Analysis of scientific investigations and publications. Among the great number of scientific papers concerning the mathematical modeling of electrical devices and numerical methods of differential equation solution we analyze some of them. At present the papers by O. M. Oleynikov, I. P. Kopylov, V. F. Syvokobylenko, A. V. Chaban are of great importance for mathematical models construction. 
Paper [2] deals with the problem of transient and stable processes in electrical engineering. The material of the book is based on classical approaches to the modeling of electrical devices and systems. Unfortunately the results of computer simulation of transient processes in engines are not presented sufficiently. The mathematical model of electromagnetic transient processes in asynchronous motors in phase coordinates and implicit numerical integration methods which are somewhat inconvenient for computer implementation is presented in paper [1]. The modeling of asynchronous motors operating modes on the basis of equivalent circuits and from the energy point of view, as well as models of asynchronous machines based on traditional methods of electric circuits, so called $L$ models, are described in papers $[4,5]$.

In our work for dynamics modes analysis we constructed $A$-model of asynchronous motor, where the differential equations are recorded for currents as variables having practical interest and normal Cauchy form. This model is the most relevant for circuit-field methods, which equations are solved by explicit numerical integration methods.

Statement of the problem. It is known that classical methods of electrical engineering based on electrical equivalent circuits of electrical devices do not allow to obtain sufficiently precise information about electro-mechanical values [7].

In the given paper the mathematical model of asynchronous motor is proposed in skew coordinates $[3,6,7]$. Such a model is constructed by means of coordinate transformations in the theory of asynchronous machines. This model makes it possible to represent the devices differential equations system in normal Cauchy form automatically. This greatly simplifies the most important stage of investigation - the computation process in computer simulation process.

Let us assume the differential equations of three-phase asynchronous motor recorded directly in normal Cauchy form in matrix form as the equations basis [7]. Since the asynchronous motor is the symmetric electricity receiver, the model is designed on the basis of two phase variables $A$ and $B$. The value of the third light phase is beyond Kirchhoff law

$$
\frac{d I}{d t}=A(U-R I)
$$

where $I, U, R$ are currents, voltages and resistances matrices

$$
I=\begin{array}{|l|}
\hline I_{S A} \\
\hline I_{S B} \\
\hline I_{R A} \\
\hline I_{R B} \\
\hline
\end{array}
$$$$
U=\begin{array}{|l|}
\hline U_{S A} \\
\hline U_{S B} \\
\hline U_{R A} \\
\hline U_{R B} \\
\hline
\end{array}
$$

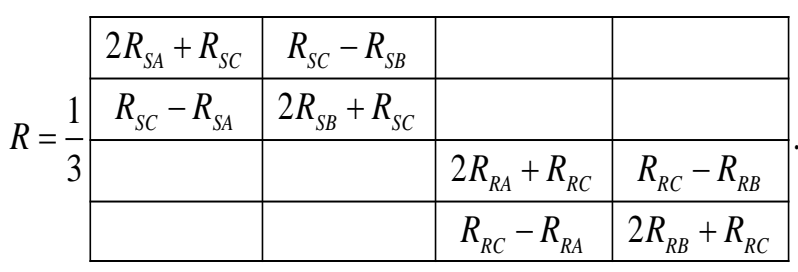

Functions of network voltage applied to the stator winding are given and angular rate of network voltage is constant $\omega=2 \pi f=2 \cdot 3,14 \cdot 50 \mathrm{~Hz}=314 \mathrm{~s}^{-1}=$ const

$$
u(t)=\frac{u_{S A}}{u_{S B}}=\frac{u_{m} \sin \omega t}{u_{m} \sin \left(\omega t-120^{\circ}\right)} .
$$

The matrix of stator and rotor winding resistances (2) also degenerates into scalar $R_{S A}=R_{S B}=R_{S C}=R_{S} ; R_{R A}=R_{R B}=R_{R C}=R_{R}$.

Let us rewrite equation (1) in the expanded form 


$$
\begin{aligned}
& \frac{d I_{S}}{d t}=A_{S}\left(U_{S}-r_{S} I_{S}\right)+A_{S R}\left(\Omega \Psi_{R}-r_{R} I_{R}\right) \\
& \frac{d I_{R}}{d t}=A_{R S}\left(U_{S}-r_{S} I_{S}\right)+A_{R}\left(\Omega \Psi_{R}-r_{R} I_{R}\right) .
\end{aligned}
$$

Here $I_{S}, I_{R}$ are stator voltage columns and converted rotor voltage columns; $U_{S}$ is source voltage column; $\Psi_{R}$ is the column of complete flux linkage of rotor winding; $R_{S}, R_{R}$ are resistive strengths of stator and rotor windings; $A_{S}, A_{S R}, A_{R S}, A_{R}$ are coefficient matrices; $\Omega$ is angular velocity matrix [7]

$$
\Omega=\frac{\omega}{\sqrt{3}} \begin{array}{|c|c|}
\hline-1 & -2 \\
\hline 2 & 1 \\
\hline
\end{array}
$$

$A=$\begin{tabular}{|c|c|c|c|}
\hline$\alpha_{S}\left(1-\alpha_{S}\left(T+b_{A} I_{A}\right)\right)$ & $-\alpha_{S}^{2} b_{B} I_{A}$ & $-\alpha_{S} \cdot \alpha_{R}\left(T+b_{A} I_{A}\right)$ & $-\alpha_{S}^{2} b_{B} I_{A}$ \\
\hline$-\alpha_{S}^{2} b_{A} I_{B}$ & $\alpha_{S}\left(1-\alpha_{S}\left(T+b_{B} I_{B}\right)\right)$ & $-\alpha_{S}^{2} b_{A} I_{B}$ & $-\alpha_{S} \cdot \alpha_{R}\left(T+b_{B} I_{B}\right)$ \\
\hline$-\alpha_{S} \cdot \alpha_{R}\left(T+b_{A} I_{A}\right)$ & $-\alpha_{S}^{2} b_{B} I_{A}$ & $\alpha_{R}\left(1-\alpha_{R}\left(T+b_{A} I_{A}\right)\right)$ & $-\alpha_{R}^{2} b_{B} I_{A}$ \\
\hline$-\alpha_{S}^{2} b_{A} I_{B}$ & $-\alpha_{S} \cdot \alpha_{R}\left(T+b_{B} I_{B}\right)$ & $-\alpha_{R}^{2} b_{A} I_{B}$ & $\alpha_{R}\left(1-\alpha_{R}\left(T+b_{B} I_{B}\right)\right)$ \\
\hline
\end{tabular}

Here $\alpha_{S}, \alpha_{R}, \alpha_{m}$ are the inverse inductance dissipations of stator and rotor windings and the main motor inverse inductance; $\omega$ is the angular velocity of rotor rotations; $b_{A}, b_{B}, b, R, T$ are the coefficients

$$
\begin{gathered}
b_{A}=b\left(2 I_{A}+I_{B}\right) ; \quad b_{B}=b\left(I_{A}+2 I_{B}\right) ; \quad b=\frac{2}{3}(R-T) / I_{m}^{2} ; \quad R=\frac{1}{\alpha_{S}+\alpha_{R}+\rho} ; \\
T=\frac{1}{\alpha_{S}+\alpha_{R}+\tau} ; \quad b=\frac{R-T}{\psi_{m}^{2}} ; \quad b_{A}=\frac{2}{3} b\left(2 \psi_{A}+\psi_{B}\right) ; \quad b_{B}=\frac{2}{3} b\left(\psi_{A}+2 \psi_{B}\right) .
\end{gathered}
$$

In order to take into account the motor magnetic circuit saturation we use its magnetizing characteristics $\psi_{m}=\psi_{m}\left(I_{m}\right)$.

$$
\Psi_{m}\left(I_{m}\right)=\left\{\begin{array}{l}
0,49 I_{m}, \quad \text { if } \quad 0 \leq I_{m} \leq 16,8 ; \\
8,3+0,49\left(I_{m}-16,8\right)-3 \cdot 10^{-2}\left(I_{m}-16,8\right)^{2}-2 \cdot 10^{-4}\left(I_{m}-16,8\right)^{2}, \text { if } 16,8<I_{m} \leq 34,8 ; \\
0,204 I_{m}+8,1, \quad \text { if } 34,8 \leq I_{m} .
\end{array}\right.
$$

Depending on the magnetizing current we get:

$$
\tau=\left[\frac{\Psi_{m}\left(I_{m}\right)}{I_{m}}\right]^{-1} ; \quad \rho=\left[\frac{d \psi_{m}\left(I_{m}\right)}{d I_{m}}\right]^{-1},
$$

where $\tau$ and $\rho$ are main inverse motor statistic and differentiation inductances.

The module of magnetizing currents vector $I_{m}$ is derived from the formula 


$$
I_{m}=2 \sqrt{\frac{I_{A}{ }^{2}+I_{A} I_{B}+I_{B}{ }^{2}}{3}}
$$

where

$$
I_{A}=I_{S A}+I_{R A} ; \quad I_{B}=I_{S B}+I_{R B} .
$$

It should be noted that matrices (6) are recorded taking into account the machine magnetic system saturation which can occur in case of the considered motor.

The column of complete flux values are found in the following way

$$
\Psi_{R j}=\frac{I_{S j}+I_{R j}}{\alpha_{m}}+\frac{I_{R j}}{\alpha_{R}}, \quad j=A, B .
$$

The equation of electromagnetic state should be supplemented by the equation of mechanical state in order to calculate the angular velocity mentioned in (5)

$$
\begin{gathered}
\frac{d \omega}{d t}=\frac{p_{0}}{J}\left(M_{e m}-M_{m e c h}\right) ; \\
M_{e m}=\sqrt{3} p_{0}\left(I_{R A} I_{S B}-I_{R B} I_{S A}\right) / \alpha_{m},
\end{gathered}
$$

where $M_{\text {mech }}$ is the mechanical moment; $p_{0}$ is the number of magnetic poles couples; $J$ is the moment of rotor inertia; $M_{e m}$ is the electromagnetic moment.

Let us find the rotor rotational velocity by means of angular velocity, and sliding by difference of stator and rotor magnetic field velocity

$$
n=\frac{30 \omega}{p_{0} \pi} ; \quad s=\frac{n_{0}-n}{n_{0}} .
$$

The system of differential equations (4), (13) is the circuit-field $A$-model of three-phase asynchronous motor. For practical use of this model it is necessary to know the resistive strengths of stator and rotor windings $R_{S}, R_{R}$, inverse inductance dissipations $\alpha_{S}, \alpha_{R}$ of windings, the main inverse inductance dissipation $\alpha_{m}$ or magnetizing curve, the inertia moment $J$, the number of magnetic poles $p_{0}$, the stator winding voltage $U_{S}$ and mechanical moment on rotor shaft $M_{\text {mech }}$.

Let us turn to the implementation of mathematical model by explicit numerical Euler method. This method is based on the substitution of the required function by polynomial of the first degree, i. e., on linear extrapolation.

Let us consider the differential equations of our problem with zero initial conditions

$$
\frac{d x}{d t}=f(x, t), \quad x=M_{e m}, I_{S}, n ; \quad M_{e m}\left(t_{0}\right)=M_{e m}{ }^{(0)}, \quad I_{S}\left(t_{0}\right)=I_{S}{ }^{(0)}, \quad n\left(t_{0}\right)=n^{(0)} .
$$


Let us consider interval $[a, b]$ and divide it into $\mathrm{p} m$ segments by nodes $t_{k}$ with pitch $\Delta t$. The exact equation solution (16) at point $t_{k+1}$ at any of the intervals $\left[t_{k}, t_{k+1}\right] \quad 0 \leq k \leq m-1$ can be represented as Taylor series with the center at point $x_{k}$.

Let us take into account that function $f(x, t)$ is $n+1$ times differentiated by both arguments [6], i. e.

$$
x\left(t_{k+1}\right)=x\left(t_{k}\right)+\Delta t \cdot x^{\prime}\left(t_{k}\right)+\frac{\Delta t^{2}}{2 !} \cdot x^{\prime \prime}\left(t_{k}\right)+\frac{\Delta t^{3}}{3 !} \cdot x^{\prime \prime \prime}\left(t_{k}\right)+\ldots+\delta\left(\Delta t^{(n+1)}\right) .
$$

The derivatives in (17) can be calculated according to (16) in the following way

$$
\begin{gathered}
x^{\prime}(t)=f(x, t) ; \quad x^{\prime \prime}(t)=\frac{\partial f}{\partial t}(x, t)+f \cdot \frac{\partial f}{\partial x}(x, t) ; \\
x^{\prime \prime \prime}(t)=\frac{\partial}{\partial t}\left[\frac{\partial f}{\partial t}+f \cdot \frac{\partial f}{\partial x}\right]+\frac{\partial}{\partial x}\left[\frac{\partial f}{\partial t}+f \cdot \frac{\partial f}{\partial x}\right] \cdot f ; \quad x^{(n)}(t)=\frac{\partial}{\partial t}\left[x^{(n-1)}(t)\right]+\frac{\partial}{\partial x}\left[x^{(n-1)}(t)\right] \cdot f .
\end{gathered}
$$

If we assume $x=x(t)$ as exact solution (16), and then substitute $t=t_{k}$ and neglect the residual member in (17), then we get the following discrete equation

$$
\begin{aligned}
x_{k+1}(t)= & x_{k}+\Delta t \cdot f\left(x_{k}, t_{k}\right)+\frac{\Delta t^{2}}{2 !}\left[\frac{\partial f}{\partial t}\left(x_{k}, t_{k}\right)+\frac{\partial f}{\partial x}\left(x_{k}, t_{k}\right) \cdot f\left(x_{k}, t_{k}\right)\right]+\ldots+ \\
& +\frac{\Delta t^{n}}{n !}\left[\frac{\partial^{(n-1)}}{\partial t^{(n-1)}} \cdot f\left(x_{k}, t_{k}\right)+\ldots+\frac{\partial^{(n-1)}}{\partial t^{(n-1)}} \cdot f\left(x_{k}, t_{k}\right) \cdot f^{(n-1)}\right],
\end{aligned}
$$

where $0 \leq i \leq n-1, x\left(t_{0}\right)=x^{(0)}, \quad x=M_{e m}, I_{s}, n$.

Equation (17) is two-pint explicit difference scheme which make it possible to calculate all the values sequentially starting with $x_{1}$ and ending with $x_{m}$. In this case the approximation error is equal to the value of neglected summand in (17) at $\Delta t \rightarrow 0$.

If we assume that $\mathrm{n}=1$ than the desired Euler method is explicit moreover the approximation accuracy is $\delta\left(\Delta t^{2}\right)$

$$
x_{k+1}=x_{k}+\Delta t \cdot f\left(x_{k}, t_{k}\right) \text {. }
$$

Mathematical modeling. FORTRAN programming language is used for dynamic modes calculation. The integration of elecromechanical state equations is carried out by explicit Euler method. GRAPHER graphic package is used for graphic dependencies construction.

Passport nominal data of asynchronous motor 4A132M6У3: $P_{\text {nom }}=7,5 \mathrm{kWt}$, $U=380 / 220 \mathrm{~V}, n_{\text {nom }}=970 \mathrm{~min}^{-1}, \eta=0,85, \cos \varphi=0,81, R_{S}=0,58 \mathrm{Om}, R_{R}=0,363 \mathrm{Om}$, $\alpha_{S}=353 \mathrm{H}^{-1}, \alpha_{R}=228 \mathrm{H}^{-1}, \alpha_{m}=11,2 \mathrm{H}^{-1}, J=0,06 \mathrm{~kg} \cdot \mathrm{m}^{2}, p_{0}=3$.

Direct motor run-up with nominal loading $M_{\text {nom }}=70 \mathrm{Nm}$, output on its steady speed, further increase of load moment at time moment $t_{k 1}=1 \mathrm{~s}$ up to $180 \mathrm{Nm}$. In order to test overload capacity at time moment $t_{k 2}=1,5 \mathrm{~s}$, the moment on the shaft is increased up to the value $M_{\text {mech }}=260 \mathrm{Nm}$. At the end of transition process the moment is reduced to $50 \mathrm{Nm}$. 
The diagram of rotor rotation speed in time function is shown in Fig. 1. The motor reaches its steady speed $980 \mathrm{~min}^{-1}$ in a time $0,65 \mathrm{~s}$. At the same time we can observe overregulation which is possible in practice. At the moment of load rise $180 \mathrm{Nm}$, the rotor speed decreases up to $940 \mathrm{~min}^{-1}$. At the following interval the speed sharply decreases to $450 \mathrm{~min}^{-1}$ being the emergency state. After the moment reduction the motor reaches its steady speed $986 \mathrm{~min}^{-1}$.

The current phase $A$ of the stator winding is shown in Fig. 2. The starting current is approximately $125 \mathrm{~A}$, the nominal one is $18 \mathrm{~A}$. When the loads are increased, the currents are increased as well up to $47 \mathrm{~A}, 77 \mathrm{~A}, 120$ A relatively and at the moment of load reduction 13 A. Long-term operation in the overload mode is unacceptable as they are emergency modes.

The dependence of electromagnetic torque and motor mechanical characteristic at starting up and setting on steady process $\left(0<t<t_{k 1}\right)$ is shown in Fig. 3, 4.

The values of current, torque and rotation speed calculated according to the model are precisely the classical theory of electrical machines calculation.

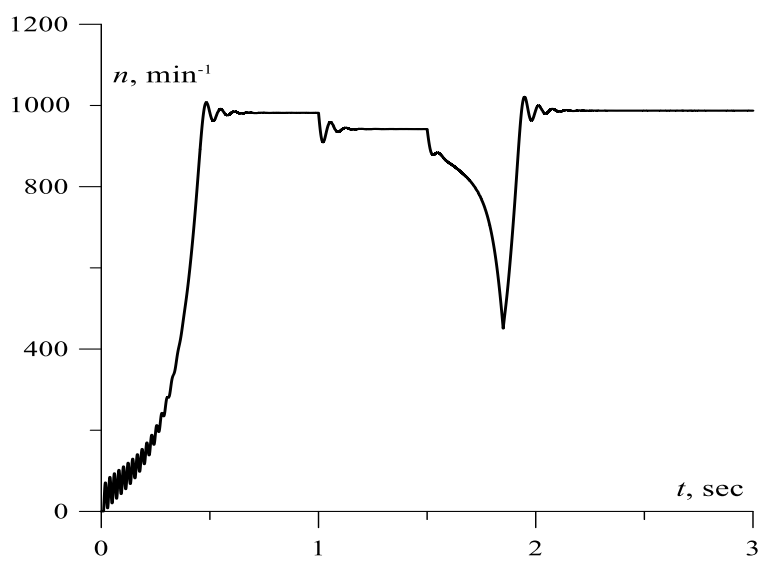

Figure 1. Time dependence of rotation speed of asynchronous motor rotor

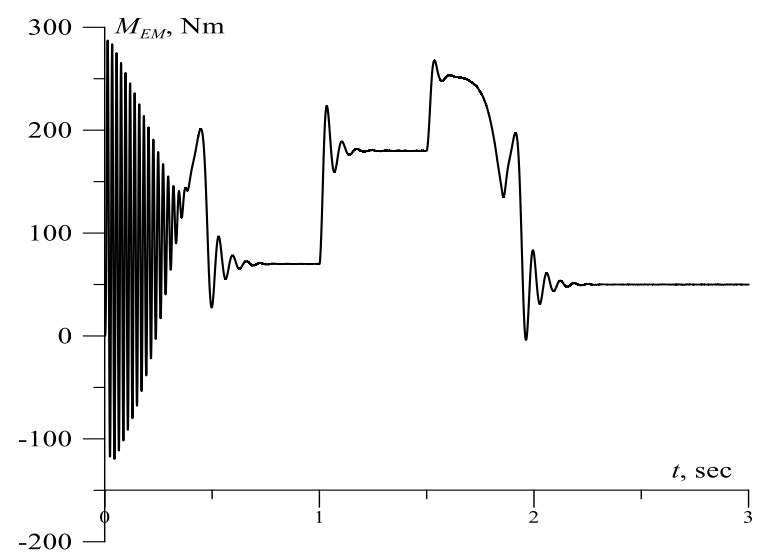

Figure 3. Stator winding transient current

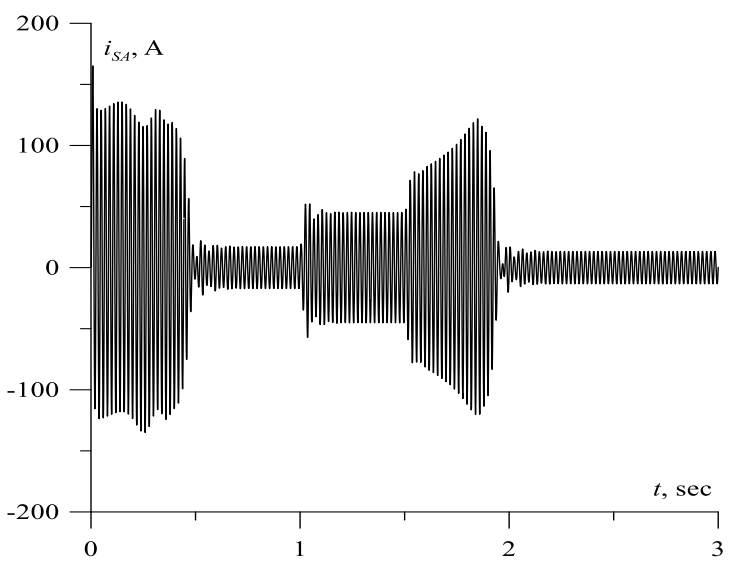

Figure 2. Stator winding transient current

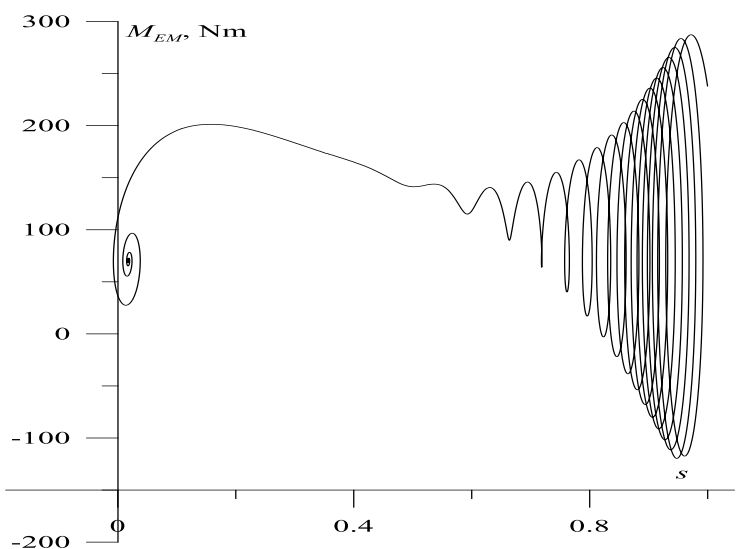

Figure 4. Mechanical characteristic of asynchronous motors $M_{e m}=f(s)$

Conclusions. The mathematical model of asynchronous motor on the basis of differential equations recorded in normal Cauchy form taking into account electromagnetic connections of motor electric circuitry and their nonlinearity providing electromagnetic and electromechanical processes modeling in steady and transitional operating modes is developed. Dynamic processes at start-up, steady speed setting, changing loads, which make it possible to determine the optimal motor operating modes, to operate it properly and to prevent emergency modes, are investigated. The results of computer experiment proved that the calculation most closely approximates the real processes. 


\title{
References
}

1. Vas'kovskyy Yu. M. Matematychne modeliuvannia electromekhanichnykh peretvoriuvachiv energii. Kyiv: KPI, 2003. 164 p. [In Ukrainian].

2. Kopylov I. P. Matematicheskoje modelirovanije electricheskikh mashin. Moscow: Vysshaja shkola Publ., 2001. 327 p. [In Russian].

3. Lyshuk V. V., Selepyna Y. R. Matematychne modeliuvannia dynamichnykh rezhymiv hlybokopaznykh asynkhronnykh dvyhuniv. Visnyk TNTU imeni I. Puliuja. 2014. No.4 (76). P. 210-223. [In Ukrainian].

4. Ong Chee-Mun. Dynamic Simulation of Electric Mashinery. New Jersej, 1998. 626 p.

5. Syvokobylenko V. F., Vasylets' S. V. Matematychna model' asynkhronnoho dvyhuna z urakhuvanniam nasychennia stali ta vytisnennia strumu v rotori. Modeliuvannia ta informatsiyni tekhnolohii. 2013. No. 69. P. 3-10. [In Ukrainian].

6. Chaban V. Chysel'ni metody. L'viv: L'vivs'ka politekhnika, 2001. 186 p. [In Ukrainian].

7. Chaban V. Electromahnitni protsesy. L'viv: Prostir M, 2017. 412 p. [In Ukrainian].

\section{Список використаної літератури}

1. Васьковский Ю. М. Математичне моделювання електромеханічних перетворювачів енергії. К.: КПІ, 2003. $164 \mathrm{c}$.

2. Копылов И. П. Математическое моделирование электрических машин. М.: Высшая школа, 2001. $327 \mathrm{c}$.

3. Лишук В. В., Селепина Й. Р. Математичне моделювання динамічних режимів глибокопазних асинхронних двигунів. Вісник ТНТУ імені І. Пулюя. 2014. № 4 (76). С. 210-223.

4. Ong Chee-Mun. Dynamic Simulation of Electric Mashinery. New Jersej, 1998. 626 p.

5. Сивокобиленко В. Ф., Василець С. В. Математична модель асинхронного двигуна з урахуванням насичення сталі та витіснення струму в роторі. Моделювання та інформаційні технології. № 69. 2013. C. 3-10.

6. Чабан В. Чисельні методи. Львів: Львівська політехніка, 2001. 186 с.

7. Чабан В. Електромагнітні процеси. Львів: Простір М, 2017. 412 с.

\section{УДК 519.876.5; 621.313.33}

\section{СИМУЛЯЦІЯ ДИНАМІЧНИХ РЕЖИМІВ В АСИНХРОННОМУ ДВИГУНІ}

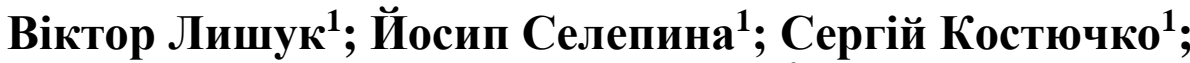 Сергій Літковець}

\author{
${ }^{1}$ Луцуький націіональний технічний університет, Луц̧ьк, Україна \\ ${ }^{2}$ Національний університет водного господарства та \\ природокористування, Рівне, Україна
}

\begin{abstract}
Резюме. Побудовано математичну модель асинхронного трифазного двигуна, щзо враховує насичення магнітної системи. Це так звана А-модель двигуна, в якій у матрииі коефіиієнтів фігурують обернені індуктивності двигуна. Система диференціальних рівнянь електромагнітного стану сформована в нормальній формі Коші, записана в матричні формі $і$ є дуже зручною для чисельного інтегрування, оскільки вона реалізується явними методами, щео є простішими в комп 'ютерній реалізацї, ніж неявні. Це дає змогу позбутись операцій чисельного обертання матриці коефіцієнтів на кожному кроці інтегрування, а також віднімання двох близьких за значенням величин основного й робочого потокозчеплень. Відповідно мінімізуються затрати комп'ютерного часу й підвищується точність розрахунку. Такий підхід дає змогу описати складні фізичні процеси у двигуні, а саме, ефект насичення магнітопроводу та механічний обертовий рух. Просимульовано пуск двигуна, вихід на усталену швидкість обертання, а також подальшу зміну навантаження на валу двигуна. Використання запропонованої моделі асинхронного двигуна, створеної за його реальними паспортними даними, дає можливість для адекватного моделювання в реальному часі. Модель оперує фізичними величинами, а саме струмами $в$ обмотках двигуна, щчо мають практичний інтерес, $і$ може бути застосована для розрахунку та аналізу перехідних прочесів. При побудові моделі використано мову програмування FORTRAN $i$ графічний редактор GRAPHER. Для чисельного інтегрування диференціальних рівнянь використано явний метод Ейлера. Проведено дослідження та аналіз електромагнітних і механічних прочесів. Запропонована модель може бути використана для аналізу режимів роботи двигуна як автономного елемента, так $і$ елемента електромеханічної системи. Показано, що ия модель відповідає класичній теорії електричних машин. методи.

Ключові слова: диференціальні рівняння, математична модель, асинхронний двигун, числові

